\title{
IMPLICATION OF GROUP COMPANY EXPANSION TO MONOPOLY PRCTICE AND UNFAIR BUSINESS COMPETITION (Study Case : Coal Mining Industry)
}

\author{
Dr. Ir. Hartana, S.H., M.M., M.H \\ Presiden Direktur Sinarmas Jakarta \\ Email : hartana_palm@yahoo.com
}

\begin{abstract}
In relation with the coal mining business growth in Indonesia for the past 10 years, than it must also supported with the fulfillment of the applicable Laws, than the purpose of this disertation are, first, to know and to find the Laws which specifically regulates the expansion buoying of Group Company especially in coal mining sector. Second, to know about the implementation of Group Company expansion in coal mining sector. Third, to know, analyze, and to find the implication of Group Company expansion in mining sector toward monopoly practice and unfair business competition. The results of this research are, First, that the Law No. 4 Year 2009 regarding Mineral and Coal Mining regulates about the buoying of group company, mentioning that the IUP and IUPK owners are banned from involving their sister company and/or their affiliation in mining service industry located in their mining area, except they have the Minister's License. Meanwhile maximum area ownership of IUP in group company is not restricted. Second, the most common group expansion in coal mining industry are by establishing holding company, acquisition and joint venture. The principal motive of these actions are economy and psychology. Third, group company expansion in coal mining industry implicates on abuse of dominant position and market control. The consequence are the addition of several new companies and also directly implies the ownership of the subsidiary's shares by the parent company. Of the 5 (five) coal mining companies studied when doing corporate actions, so that into 1 (one) group companies, the amount of coal production does not reach 50\%. It is not proven to be denied Article 17 of Law no. 5 of 1999.
\end{abstract}

Key words : Expansion Regulation, Expansion Practice, Fairness in Competition

\section{Introduction}

In the last ten years there has been a rapid growth of coal mining companies in Indonesia. This is due to the increasing demand for coal as an energy supply in the future which makes this industry has a very big attraction for investors. Coal is one of the important energy commodities in Indonesia. Mining has been underway since the Dutch Colonial period. Coal mining by Dutch Colonial was 
first performed on the island of Borneo and Sumatra Island which is currently the main producer of coal in Indonesia (Irwandy, 2014).

Coal exploitation was first performed in Pengaron, South Kalimantan, in 1849 by NV Oost Borneo Maatsnhappij "Golden Fortress". Furthermore, the Netherlands also established two other coal mining companies near Martapura, namely Julia Hermina and Delft. In 1888, coal mining was opened in Batu Panggal, Kutai, East Kalimantan by L.H. Menten. Menten also opened the first petroleum exploitation effort in the Kutai region (Irwandy, 2014).

Coal investigation continues. Coal investigations in 1915-1918 in South Sumatra resulted in new coal resources and reserves. In 1919, the Dutch opened a coal mine in Tanjung Enim with an open pit method at the Water Laya mine. In 19231940, mining was done by underground mining method. The fulfillment of commercial interests began in 1938 by Bukit Asam coal mining, namely on Air Laya for bituminous and Suban coals for semi-anthracite coal types. In 1950, the Government of the Republic of Indonesia authorized the formation of the State Company of Tambang Arbor Bukit Asam (PN TABA) as the end of the Dutch colonial government (Irwandy, 2014).

Many coal companies apply for Mining Business License (IUP). According to Jero Wacik, the government has set the project to build the steam power plant, in addition to the 10,000 Megawatt (MW) phase II project which is the majority of coal-fired power plants, plus the 7,000 MW steam power plant which is a breakthrough to anticipate the lack of electricity supply in Java by 2018 (http:/ / finance.detik.com).

During the reign of President Joko Widodo, the steam power plant construction project continues. The power plant project is sheltered in the 35,000 MW program and is expected to be completed within the next 5 (five) years. The inauguration of this project was conducted at Samas Beach, Bantul, Yogyakarta on May 4, 2015. President Joko Widodo confirmed that the 35,000 MW project is not an ambitious infrastructure project. On the same occasion, President Joko Widodo also said that the government has a debt to the people that must be met because many people of Indonesia who have not enjoyed electricity (http:/ / finance.detik.com).

Companies engaged in mining in Indonesia are usually in the form of groups. There are 30 groups engaged in Indonesian mining industry, among them are BUMI Plc Group, ADARO Group, BAYAN Group, INDIKA Group, BANPU Group, BA Group, BORN Group, TANITO Group, ASTRA Group, SINAR MAS Group and many others. The dominance of the existence of group companies 
rather than single companies in Indonesia is shown by large-scale companies are no longer run through a single company, but using the company's construction group (Sulistiowati, 2011).

The group companies continue to expand their business in the coal mining sector. Of course the goal is to earn a return on investment and contribute to broader economic and social improvements in the environment. To achieve its objectives, the group companies are facing increasingly fierce competition from competitors who share the same goals, with the products offered and similarly similar ways.

Beginning in 2009, the Minister of Energy and Mineral Resources shall issue a Ministerial Decree on Stipulation of Minimum Needs and Percentage of Coal Sales for Domestic Interest and in accordance with the Decree of the Minister of Energy and Mineral Resources no. 2805 K / 30 / MEM / 2015 on Stipulation of Minimum Needs and Percentage of Coal Sales for Domestic Interests 2015 stipulates that the estimated demand for DMO coal for 2015 is 92.310 .000 ton or $23.4071 \%$ of total national production of 394,367. 524 tons. The estimated coal demand will be allocated to several national industries, namely PLTU, Metallurgy, Fertilizer, Cement, Textile, Paper and Briquettes.

Seeing the dynamics of the development of group companies, especially those engaged in the coal sector, there are only a few group companies that control the national coal production. Such conditions can not be allowed to continue to continue because there will be a great inefficiency, thus harming the business competition climate. Monopolistic practices and unfair business competition are assumed to be risky, given the expansion of the business of group companies through its subsidiaries in the coal mining sector is still ongoing until now. Therefore, we need a legal product that can prevent or minimize the mastery of production and marketing of coal by certain groups or groups.

The coal mining sector is vulnerable to monopolistic practices and unhealthy business competition, both in the area of control, share ownership and marketing of coal. The phenomenon that occurs in the mining sector is currently the mastery of companies in the form of groups. Indonesia does not yet have a legislation that specifically regulates the group companies. The corporate regulatory framework incorporated in the group companies still uses a single company approach. Therefore, until now there has been no juridical recognition of the group companies (Sulistiowati, 2010).

The authors suspect that the expansion of group companies in the coal mining sector resulted in monopolistic practices and unfair 
business competition reinforced by the findings of the Business Competition Supervisory Commission (KPPU) Balikpapan which is conducting research related to the Mining Business License (IUP) issued by the local government before the year 2010 . From the preliminary findings, KPPU Balikpapan suspects that there is a monopolistic practice of coal mining business in Berau District, East Kalimantan Province. Therefore, the title of the research raised by the author to be a topic or discussion on this Dissertation is "Implication of Group Company Expansion to Monopoly Prctice and Unfair Business Competition (Study Case : Coal Mining Industry)".

\section{A. Main Problem}

1. What is the regulation of limiting the expansion of group companies in the coal mining sector in terms of legislation?

2. How does the expansion of group companies in the coal mining sector occur?

3. What is the implication of the expansion of group companies in Indonesia, especially in the coal mining sector against monopolistic practices and unfair business competition?

\section{B. Objectives}

1. The first objective of this study is the authors want to know and find the legislation that regulates specifically about the limitation of corporate expansion. The existence of relevant legislation is important to be known by the author because in this study the author uses the juridical empirical approach.

2. The second goal of this research is the author wants to know about the implementation of the company's expansion that occurred in the coal mining sector. This research is focused on the ways used to expand and the parties involved in the expansion of the company.

3. The third purpose of this study is the authors want to know, analyze and find the implications of the expansion of group companies in the mining sector against monopolistic practices and unfair business competition. Surely researchers should analyze more deeply to find out the answer.

\section{Research Methods}

The study entitled " Implication of Group Company Expansion to Monopoly Prctice and Unfair Business Competition (Study Case : Coal Mining Industry)" is empirical juridical.

\section{Literature Review}

1. Corporate Expansion

The company must make a breakthrough in order to maintain 
its continuity through business development investment or more commonly known as corporate expansion. Expansion is a manifestation of the desire to maintain the existence of the company in the long term. The company was not founded with a view to stop after earning a temporary profit. Expansion is done to provide growth for the company. Expansion is to enlarge the company either by establishing new businesses with new products or products that already exist elsewhere or also increasing the production of goods that have been produced.

Companies that want to maintain their survival must be sensitive to opportunities and threats. It is intended as part of efforts to achieve a better corporate life by meeting the needs of consumers. Bambang Riyanto explained in the context of expansion, there are two main motives underlying a company to expand, namely economic motives and psychological motives (Riyanto, 1999).

\section{Group Company}

Group companies have an increasingly important role in business activities in Indonesia. Group companies become the most widely chosen business establishments in Indonesia. Group companies are an arrangement of companies that are juridically independent and one with another is an economic entity led by the parent company (Simanjuntak, 2008).

The absence of juridical acknowledgment of the legal entity status of the group companies caused the laws and regulations not to regulate the construction of group companies. In contrast, statutory firms still use a single-company approach from corporations that are constituents of group companies, so that legislation still retains formal legal recognition from the status of the parent and subsidiary legal entities. The relationship between the parent and the subsidiary in the construction of a group company does not remove juridical independence from the status of the legal entity of the parent and its subsidiaries, even though the subsidiary is subject to the control of the parent company (Sulistiowati, 2009).

National Institute of Statistics and Economic Studies, A group of companies is an economic entity formed of a set of companies which are either companies controlled by the same company, or the controlling company itself. Controlling a company means having the power to appoint the majority of its directors. The control of company A by company B may be direct (company B directly holds the majority of voting rights on the management board of company A) or indirect (B controls intermediate companies $\mathrm{C}$, D or $\mathrm{E}$, etc, which it can ask to vote the same way on the management 
board of $\mathrm{A}$, there by obtaining a majority of rights) (http://www.insee.fr).

The South African Institute of Chartered Accountants (SAICA), group company is a group of companies as two or more companies that share a holding company or subsidiary relationship. A holding company in relation to the subsidiary is defined as a juristic person or undertaking that controls a subsidiary. Therefore the determination of whether a company is a holding company depends on one of the following (https://www.saica.co.za):

a. The ability of the holding company to directly or indirectly exercise, or control the exercise of, a majority of the general voting rights at a general meeting, or

b. The right to appoint or elect, or control the appointment or election of, directors of that company who would control a majority of the votes at a board meeting, or (A. Rhoades).

c. All the general voting rights associated with issued securities of the company are held or controlled by persons contemplated in (1) and (2).

\section{F. Discussion}

1. Expansion of Group Companies Judging from Law of The Republic of Indonesia Number 4 of 2009 Concerning Mineral and Coal Mining
In Law of The Republic of Indonesia Number 4 of 2009 Concerning Mineral And Coal Mining explained that Mining Business License (IUP) consists of two stages:

a. Exploration IUP, covering general investigation, exploration and feasibility studies;

b. Production Operation IUP, including construction, mining, processing and refining activities, as well as transportation and sales.

Furthermore, it is also explained that the holders of IUP Exploration and holders of Production Operation IUP can perform part or all of the activities. In the sense that IUP holders, both exploration and production operations, have the discretion in carrying out their business activities, depending on the financial, human and technological capabilities of IUP holders.

IUP is granted by Regent/Mayor, Governor or Minister in accordance with their authority, that is:

a. IUP is granted by the Regent/mayor if the WIUP (Mining Permit Territory) is within regency/municipality territory;

b. IUP shall be granted by the Governor if the WIUP is located across the district/municipal territory within 1 (one) province after 
obtaining a recommendation from the local bupati/mayor in accordance with the provisions of legislation; and

c. IUPs are granted by the Minister if WIUP is located across the province after obtaining a recommendation from the local governor and regent/mayor in accordance with the provisions of legislation.

That minerals and coal contained within mining jurisdiction of Indonesia are nonrenewable natural riches God Almighty has granted, and have important roles in meeting the life of many people; therefore, the management thereof is subject to control by the State to bring real added value to the national economy in efforts to arrive at public welfare and prosperity in a just manner. That mineral and coal mining business activities that constitute mining business activities other than geothermal, petroleum and natural gas, and ground water have important roles in bringing continuously real added value to the national economic growth and development in regions.

Article 33 section (3) of the 1945 Constitution asserts that the land, the waters, and the natural riches contained therein shall be controlled by the state and exploited in the greatest prosperity of the people. Given minerals and coal as natural riches contained in the land are nonrenewable natural resources, the management thereof needs to be optimally conducted in efficient, transparent, sustainable, environmentally-sound, and just manners in order to reap the continuous benefits in the greatest prosperity of the people. To implement the provisions of Article 33 section (3) of the 1945 Constitution, Law Number 11 of 1967 concerning Basic Provisions on Mining is thus enacted. The Law has about four decades since its enactment given important contributions to national development.

As time passes, the law with centralized contents no longer keeps pace with the current situations and future challenges. In addition, mines development must adjust itself to both national and international strategic environmental changes. The primary challenge faced by mineral and coal mining is the globalization effects that push democratization, regional autonomy, human rights, the environment, technology and information developments, intellectual property rights and demands for improved private and public participation. To face the strategic environmental challenges and in response to the number of issues, it is necessary to prepare new laws and regulations in the field of mineral and coal mining to legally base a reform move and reorganization of management and business of mineral and coal mining. 
2. Implementation of Group Expansion Group that Occurs in Coal Mining Sector.

a. Establish Holding Company Holding company is a form of development that arises in a limited liability company in Indonesia. However, corporate law in Indonesia has not been regulated legally about holding company. Therefore there is no official understanding of holding company. However, there are several terms that are defined as a holding company such as a group company, parent company, or parent company. When referring to the terminology used in the Public Utility Holding Company Act in the United States, the definition of a holding company is "A corporation formed for the express purpose of controlling other corporations by the ownership of a majority of ther voting capital stock. In common usage, the term is applied to any corporation which does in fact control other corporations commonly referred to as subsidiaries (Sulistiowati, 2010)." b. Joint Venture

There are many reasons someone or a business entity does a Joint Venture. Partnering with a person or business entity with large capital, having an advanced distribution of goods and technology is one of the reasons for joint venture. VR Business Sales Edmonton, mentioned the definition of Joint Venture is : "A joint venture is a strategic alliance between two or more individuals or entities to engage in a specific project or undertaking. Partnerships and joint ventures can be similar but in fact can have significantly different implications for those involved". There are several reasons for the company to joint venture, among others:

a. Market Access: The early cases of JVs were ones that provided access to international end markets for growth. This remains a popular (albeit declining) rationale for JVs, especially in consumer facing industries and markets with foreign ownership restrictions. The extent of globalism has now reduced the importance of this rationale;

b. Syndication of Capital \& Risk: The sharing, or syndication, of capital and/or risk is a second reason for a JV. This is especially true for capitalconstrained private companies, for large-scale capital projects in the resource, power and infrastructure sectors, and for smaller companies in the relatively risky technology and biopharma sectors;

c. Economies of Scale: As we saw with the case of Infineum, JVs may confer the potentially significant advantages of relevant scale. But this does not simply mean an increase in size; coherence - the complexity, range, and related nature - is an equally 
significant factor in sustaining a competitive advantage. Together, size and coherence create the relevant scale that helps companies gain the depth and expertise they need if they are to deploy their assets and capabilities effectively. This insight may seem simple, but represents a critical evolution beyond the conglomerate mindset of the past 40 years - a mindset that formerly focused on size alone, with insufficient emphasis on coherence;

d. Capabilities \& Positional Assets: The continuous growth of advantaged positional assets and organizational capabilities has been linked to sustained growth and financial success. There are only three ways to develop the capabilities necessary for profitable growth.

3. Implications of Expansion of Group Companies in the Coal Mining Sector in Indonesia

a. Analysis of Group Companies Expansion Implications in the Coal Mining Sector Against Monopolistic Practices and Unfair Business

Competition

The company must make a breakthrough in order to maintain its continuity through business development investment or more commonly known as corporate expansion. Expansion is a manifestation of the desire to maintain the existence of the company in the long term. The company was not founded with a view to stop after earning a temporary profit. Expansion is done to provide growth for the company. Expansion is to enlarge the company either by establishing a new business with new products or products that already exist elsewhere or also increase the production of goods that have been produced.

The expansion of group companies in the coal mining sector has several implications, among others: Dominant Position, In Law Of The Republic Of Indonesia No.5 Of 1999 Concerning The Ban On Monopolistic Practices And Unfair Business Competition, dominant position is defined as follows : Dominant position is a situation where an entrepreneur does no tha veany significant competitor in the relevant market with regard to the market share being controlled, or the entrepreneur is in the highest position among its competitors in the relevant market with regard to its financial capability, ability to have access to the suppliers or sales, and ability to adapt to the supply and demand of certain goods or services.

in Article 25 of Law no. 5 Year 1999 explained that:

(1) Entrepreneurs are prohibited from taking advantage of their dominant 
position, either directly or indirectly, in order to:

a. impose trade terms with the intention to prevent and/or hamper the consumers to acquire competitive goods and/or services, both in prices or quality; or

b. restrictthemarketandtec hnologydevelopment;or

c. hamper other entrepreneurs having the potential to become their competitors to enter the relevant market.

(2) Entrepreneurs are in the dominant position as referred to under Paragraph

(1) of this article if:

a. one entrepreneur or a group of entrepreneurs controls $50 \%$ (fifty percent) or more of the market share on one type of goods or service; or

b. twoorthreeentrepreneur sorgroupsofentrepreneu rscontrol75\% (seventy five percent) or more of the market share on one type of certain goods or services

The provision of dominant position regarding the control of market share determined by Article 25 paragraph (2) requires that business actors having dominant position can distort the market either directly or indirectly. Then the question arises, whether the $50 \%$ or $75 \%$ is absolute? Normatively, the provision of Article 25 paragraph (2) is illegal in the sense that if the business actor already controls $50 \%$ market share for one business actor and $75 \%$ for two or three business actors, then the control of the market share is directly prohibited as it proves to violate the practice monopoly and unhealthy business competition. If the per se approach is illegally applied to Article 25, it is the same as obstructing the purpose of Law no. 5 Year 1999, which is to encourage business actors to develop based on fair business competition. However, in practice KPPU has applied the provisions of Article 25 with the rule of reason approach. This is to conform with the provisions of Article 4, Article 13, Article 17 and Article 18 of Law no. 5 of 1999 which uses the approach of rule of reason in its application. Practically speaking, if Article 25 applies to the per se approach, it will limit the development of efficient and innovative business actors in the relevant market.

\section{c. Legal Considerations of Expansion of Group Companies Against Monopolistic Practices and Unfair Business Competition \\ Law no. 5 of 1999} Concerning Prohibition of Monopolistic Practices and Unfair Business Competition, the expansion of group companies which is indicated to occur in 
several companies in Indonesia currently needs to be examined the balance through approaches:

1). Rule of Reason

It is an approach to evaluate the effect of a particular agreement or business activity to determine whether an agreement or activity is inhibiting or supporting the competition. With this approach, it can be seen whether the business actor's actions have implications for fair or unhealthy business competition through economic analysis which in its application in inspection process in KPPU using the keyword "prohibited" and "allegedly". The evaluation by KPPU is basically to assess whether this expansion activity violates antitrust law or not and such expansion activities hamper or support business competition.

This approach can be seen from the provisions of the articles with the inclusion of the words "which can result" and / or "predictably", the words imply the need for more in-depth research into whether an action or activity may lead to a monopolistic practice that is inhibiting a agreement. The expansion of group companies is closely related to the application of Rule of Reason because in its application not only required knowledge of law but also economics because expansion means there is a significant business expansion also happened economic expansion in one business group, in this case is group company. The legal and economic expansion within a business group has the potential for monopoly, which in the discussion of this expansion is indicated through the existence of the keyword "prohibited" and "predictable" through Law no. 5 Year 1999:

a) Article 17 stating that the expansion activity is suspected or considered to be a monopoly;

b) Article 19 stating the notion of prohibition and suspicion;

c) Article 25 indicated can be conducted inspection process in KPPU through Rule of Reason and Per Se Illegal approach because there is keyword "prohibited" in paragraph 1 and keyword "allegedly" in paragraph 2

2). Per Se Illegal

It is an approach that states any business or business dealings as illegal, without further verification of the effects of such agreements or business activities, the benefits being the ease and clarity in the administrative process, in addition to having a self-aggregate force rather than a prohibition -a declaration that is still dependent on the evaluation of the complicated market influence which in its application in the examination process in KPPU uses the keyword "prohibited".

\section{Conclusion}

1. Arrangement of the expansion of group companies shall be regulated 
in several laws and regulations, including:

a. Law no. 4 of 2009 Concerning Mineral and Coal Mining, provides strict regulation on the expansion of the company's restrictions on the use of mining service companies. IUP or IUPK holders are prohibited from involving their subsidiaries and / or affiliates in the field of mining services business in the mining business areas they work on, except with the permission of the Minister. Meanwhile, the maximum ownership of IUPs owned as a result of expansion of group companies is not expressly regulated in this Law.

b. Law 5 of 1960 Concerning Basic Regulation of Agrarian Principles, provides strict regulation which is further stipulated in the Regulation of the Minister of Agrarian Affairs and Spatial / Head of National Land Agency Number 5 Year 2015 on Location Permit provides restrictions on group companies that are broadly bound and the term of use, ownership or control of the land. The type of business regulated is the business of housing and residential

development, Industrial Estate business, plantation business which is cultivated in the form of large plantations with the Right to Use Enterprises, and pond business. The validity period is given for a period of 3 (three) years and can be extended for a period of 1 (one) year. However, the Mining Business License (IUP) is not covered under this legislation. The right to IUP or IUPK is not the ownership of land rights. Therefore, if mining activities have been completed by the IUP (reclamation and revegetation obligations have been fulfilled), then the land must be returned to the State.

2. In the coal mining sector, the dominant expansion is carried out by business actors by 3 (three) ways, namely forming a holding company, acquisition, and joint venture. The types of acquisitions that are often done in the mining sector are Acquisition of Shares and Acquisitions of Business Activities. Both types of acquisitions are easier to 
implement because the acquirer company has everything in the form of Human Resources and Capital which is the main requirement for the acquirer company to acquire can run quickly, easily and safely. By exercising the acquisition of a majority share, the acquirer may control the management and operation of the company including taking all of the company's liabilities acquired against a third party. Thus, the acquirer can control and regulate the company's financial and operational policies. In addition, by acquiring business activities, the acquisition company can adapt quickly because it has mastered the business network, production equipment, intellectual property, etc., so that the company can rapidly develop to grow even more. There are two main motives of a company to expand, namely economic motives and psychological motives. The economic motive is based on consideration to enlarge the profit earned. Psychological motive is done not pay attention to economic calculation. This kind of expansion is based on the personal ambition of the company owners to gain prestige and greater power.
3. The expansion of group companies in the coal mining sector has implications for Abuse Dominant Position and Market Control. One thing that can not be avoided from the expansion of a company or diversification of this business is the addition of several new companies and also directly implies the ownership of shares of a subsidiary by the parent company. This affiliated relationship is regulated in Article 26 and Article 27 of Law No. 5 Year 1999 concerning Multiple Positions and on Cross Ownership of Shares. Affiliation relationships that result from multiple positions by a person in some company or cross stock ownership in some companies may affect the policy of the business actor, since that influence can control the company. Ultimately such influence may affect competition in relevant markets in certain industries. In the meantime, market dominance or in other words become the ruler in the market is the desire of almost all business actors because the domination of a large market has a positive correlation with the level of profit that may be obtained by business actors. Parties that can 
control the market are business actors who have market power, ie business actors who can control the market, so it can determine the price of goods and / or services in the market concerned. Of the 5 (five) coal mining companies studied when doing corporate actions, so that into 1 (one) group companies, the amount of coal production does not reach $50 \%$. It is not proven to be denied Article 17 of Law no. 5 of 1999 .

\section{References}

Irwandy, Arif, 2014, Batubara Indonesia, Jakarta, PT. Gramedia Pustaka Utama.

National Institute of Statistics and Economic Studies. "Group of companies" Diakses dari: http://www.insee.fr/en/m ethodes/default.asp?page= definitions/group -societesentreprises.htm.

Pada tanggal 2 September 2014.

Rista Rama Dhany. “Jero: Masa Depan Pengusaha Tambang Batu Bara Akan Cerah". Diakses dari http:/ / finance.detik.com/re $\mathrm{ad} / 2014 / 03 / 07 / 161757 / 251$ 8939/1034/jero-masadepan-pengusaha-tambangbatu-bara-akan-cerah pada tanggal 14 November 2014.

Rista Rama Dhany. "Resmikan Proyek Listrik 35.000 MW, Jokowi: Ini Bukan Proyek
Ambisius". Diakses dari http:/ / finance.detik.com/re ad/2015/05/04/125155/290 $4887 / 1034 /$ resmikanproyek-listrik-35000-mwjokowi-ini-bukan-proyekambisius pada tanggal 20 Juni 2015.

Riyanto, Bambang, 1999, “Dasardasar Pembelanjaan Perusahaan", Edisi ke Empat. Yogyakarta: BPFE.

Simanjuntak, Emmy Pangaribuan, 2008. “Hukum Perusahaan Kelompok dan Globalisasi Usaha (Concern)". Bahan Ajar Mata Kuliah Hukum Dagang Internasional. Universitas Gadjah Mada, Yogyakarta. Stephen A. Rhoades, The Effect of Bank-Holding-Company Acquisitions of Mortgage Bankers on MortgageLending Activity, The Journal of Business, Vol. 48, No. 3 (Jul., 1975), The University of Chicago Press.

Sulistiowati, 2009, Keterikatan Induk Dan Anak Perusahaan Dalam Konstruksi Perusahaan Kelompok Dan Implikasinya Kepada Kelompok Ketiga Di Indonesia, Disertasi Fakultas Hukum Universitas Gadjah Mada Yogyakarta.

Sulistiowati, 2010. Aspek Hukum dan Realitas Bisnis Perusahaan Group di Indonesia. Jakarta: Erlangga. Sulistiowati, 2010. Aspek Hukum dan Realitas Bisnis Perusahaan 
Group di Indonesia. Jakarta: Erlangga.

Sulistiowati, 2011. "Limited Liability Dalam Limited Liability Pada Konstruksi Perusahaan Kelompok Piramida". Mimbar Hukum, Volume 23. Universitas Gadjah Mada.

The South African Institute of Chartered Accountants (SAICA). "The definition of a group of companies as per the new Companies Act has changed". Diakses dari: https:/ / www.saica.co.za/ta bid/1444/itemid/1784/The -definition-of-a- group -ofcompanies-as- per-the.aspx.

Pada tanggal 2 September 2014.

Undang-Undang No. 23 Tahun

2014 Tentang Pemerintahan

Daerah. 